\title{
Bone mineralisation in premature infants cannot be predicted from serum alkaline phosphatase or serum phosphate
}

\author{
J Faerk, B Peitersen, S Petersen, K F Michaelsen
}

See end of article for authors' affiliations

......................

Correspondence to: Dr Faerk, University Clinic of Paediatrics, Hvidovre Hospital, Kettegaards allé 30, 2650 Hvidovre, Copenhagen, Denmark; jfaerk@dadlnet.dk

Accepted

29 November 2001

\begin{abstract}
Background: The bone mineral content of premature infants at term is lower than in mature infants at the same postconceptional age. Serum alkaline phosphatase and serum phosphate are often used as indicators of bone mineralisation.

Objective: To analyse the association between bone mineral content and serum alkaline phosphatase and serum phosphate.

Methods: Serum alkaline phosphatase and phosphate were measured at weekly intervals during admission in 108 premature infants of gestational age below 32 weeks (mean (SD) gestational age 29 (2) weeks; mean (SD) birth weight 1129 (279) g). Bone mineral content was measured at term (mean gestational age 41 weeks) by dual energy $x$ ray absorptiometry and corrected for body size.

Results: Serum alkaline phosphatase was significantly negatively associated with serum phosphate $(p<0.001)$. Bone mineral content was not associated with mean serum alkaline phosphatase $(p=0.8)$, peak serum alkaline phosphatase $(p=0.5)$, or mean serum phosphate $(p=0.2)$ at term. Conclusion: Routine measurements of serum alkaline phosphatase and serum phosphate are of no use in predicting bone mineralisation outcome in premature infants.
\end{abstract}

$P$ remature infants born before 32 weeks of gestational age are at risk of developing metabolic bone disease. Their bone mineral content (BMC) at term has been found to be $25-70 \%$ lower than in term infants. ${ }^{12}$ The cause of metabolic bone disease is considered to be low intake of calcium and phosphorus. ${ }^{3-5}$

The use of simple biochemical indicators of bone mineralisation such as serum alkaline phosphatase and, to some extent, serum phosphate and serum calcium has been suggested to be an easy way of identifying premature infants with metabolic bone disease ${ }^{67}$ and guiding regulation of the dietary intake of calcium and phosphorus. ${ }^{4}$

Measurements of BMC are usually based on photon absorptiometry applied to the forearm. This method has the limitation of measuring only a small part of the skeleton, and correction for body size, which is necessary to assess bone mineralisation, ${ }^{8}$ is not used. $x$ Ray examination of the skeleton has also been used, and a scale for grading the severity of metabolic bone disease has been developed. ${ }^{9}$ A BMC $<50 \%$ of the normal level is usually the detection limit for changes on radiographs, which significantly limits this method. Dual energy $x$ ray absorptiometry (DEXA) is currently the "gold standard" for determining BMC because of its high precision and accuracy. ${ }^{10} 11$

Kovar et $a l^{6}$ introduced the use of serum alkaline phosphatase in screening for rickets of prematurity in a study of 30

\begin{tabular}{lr} 
Table 1 Characteristics of study infants \\
\hline Mean (SD) birth weight (g) & $1129(279)$ \\
Mean (SD) gestational age (days) & $201(14)$ \\
Males & $52(48 \%)$ \\
Small for gestational age* & $29(27 \%)$ \\
Days on ventilatort & $0(0-25)$ \\
Days on nasal CPAP & $18(0-66)$
\end{tabular}

*Birth weight $<$ the 10 th centile. †Median (range)

CPAP, Continuous positive airway pressure. infants. They suggested a cut off level of alkaline phosphatase activity above 5 times the upper limit of the normal adult reference rate (> $1200 \mathrm{IU} / \mathrm{l})$ as an indication of rickets based on four premature infants who had radiographic rachitic changes. Another radiographic study by Koo et $a l^{12}$ found a significant association between serum phosphate and bone mineralisation. Different conclusions can be drawn from the photon absorptiometry studies. Some ${ }^{713}$ report an association, although weak, between serum alkaline phosphatase or serum phosphate and BMC, whereas others do not find any associations. ${ }^{14}$ The conclusions from the regional DEXA studies also differ, with one study ${ }^{15}$ reporting no association and others reporting an association between serum alkaline phosphatase $^{16}$ and BMC or serum phosphate, but not serum alkaline phosphatase, ${ }^{17}$ and BMC. Comparison of the studies is difficult because of inconsistency in the measurements of biochemical variables and BMC. No studies so far have compared size corrected BMC measured by DEXA with biochemical indicators of bone mineralisation in premature infants.

The aim of this study was to determine the association between serial measurements of serum alkaline phosphatase and serum phosphate in premature infants during the admission period and BMC measured at term by DEXA.

\section{PATIENTS AND METHODS}

This study is part of a prospective randomised, double blind, nutritional intervention study. ${ }^{18}$ Inclusion criteria were gestational age $<32$ weeks (in most cases assessed from early ultrasound) and no major congenital malformations or inborn errors of metabolism. The study included 165 premature infants, 127 of whom completed the intervention period (from 1 week of age until 37 weeks of gestational age) and had a technically satisfactory DEXA scan at term.

Abbreviations: $B M C$, bone mineral content; DEXA, dual energy $x$ ray absorptiometry 


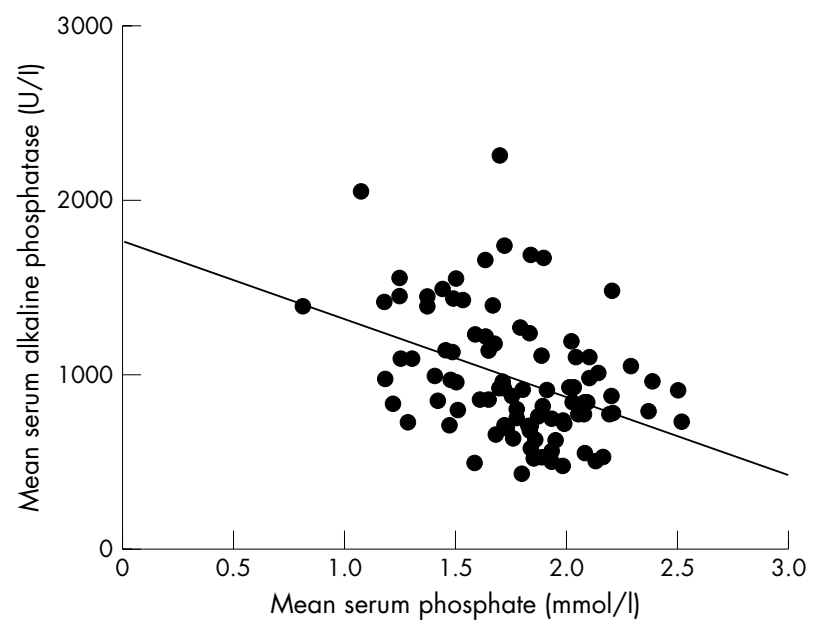

Figure 1 Association between serum phosphate and serum alkaline phosphatase. Serum alkaline phosphatase $=1762-449 \times$ serum phosphate $(p<0.001)$.

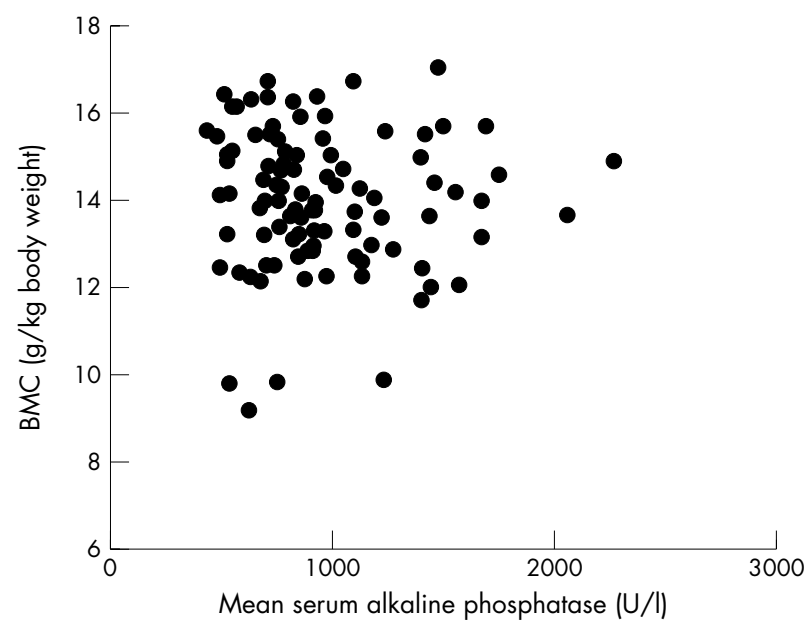

Figure 2 Association between bone mineral content (BMC) and serum alkaline phosphatase. BMC at term was not associated with mean serum alkaline phosphatase measured at weekly intervals during hospital stay $(p=0.70)$.

We included infants with four or more weekly measurements of serum alkaline phosphatase and serum phosphate according to the protocol. Alkaline phosphatase and phosphate were measured at weekly intervals for more than three weeks in 108 infants, and 19 infants had only two or three measurements. Most of the analysis is based on the 108 infants with the repeated measurements of serum alkaline phosphatase and serum phosphate. Table 1 presents descriptive characteristics of the 108 infants.

The infants who withdrew from the study $(\mathrm{n}=10$; three died) and the infants who were not DEXA scanned $(n=13)$ at term did not differ from the 108 infants with repeated measurements of serum alkaline phosphatase and serum phosphate in terms of birth weight (1131 (345) v 1129 (279) g, $\mathrm{p}=0.98)$, gestational age (204 (16) $v 201$ (14) days, $\mathrm{p}=0.32)$, weight gain (29.0 (5.8) v 27.7 (5.3) g/day, $\mathrm{p}=0.36)$, dietary intake (195 (10) $v$ 191 (12) ml/kg/day, $\mathrm{p}=0.23)$, mean serum alkaline phosphatase (1116 (459) v 954 (361) U/l, p =0.19), or serum phosphate $(1.77(0.36) \vee 1.78(0.32) \mathrm{mmol} / \mathrm{l}, \mathrm{p}=0.89)$. The BMC of the 19 infants with less than four measurements of serum alkaline phosphatase and serum phosphate was not significantly different from the 108 participating infants ( 14.5 (1.2) $v 14.1(1.5) \mathrm{g} / \mathrm{kg}$ body weight, $\mathrm{p}=0.30)$. Mean serum alkaline phosphatase and phosphate in the 12 DEXA scanned

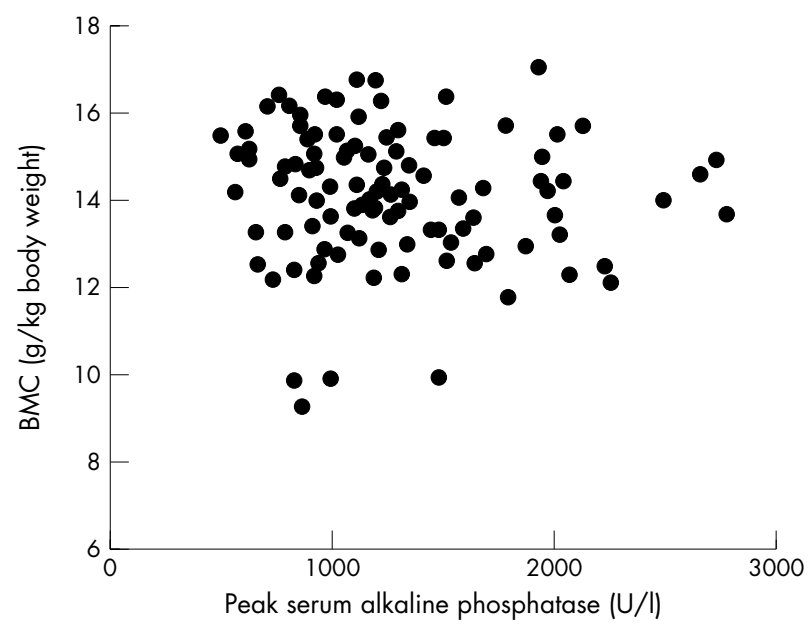

Figure 3 Association between bone mineral content (BMC) and peak serum alkaline phosphatase. BMC at term was not associated with the peak level of serum alkaline phosphatase during hospital stay $(p=0.41)$.

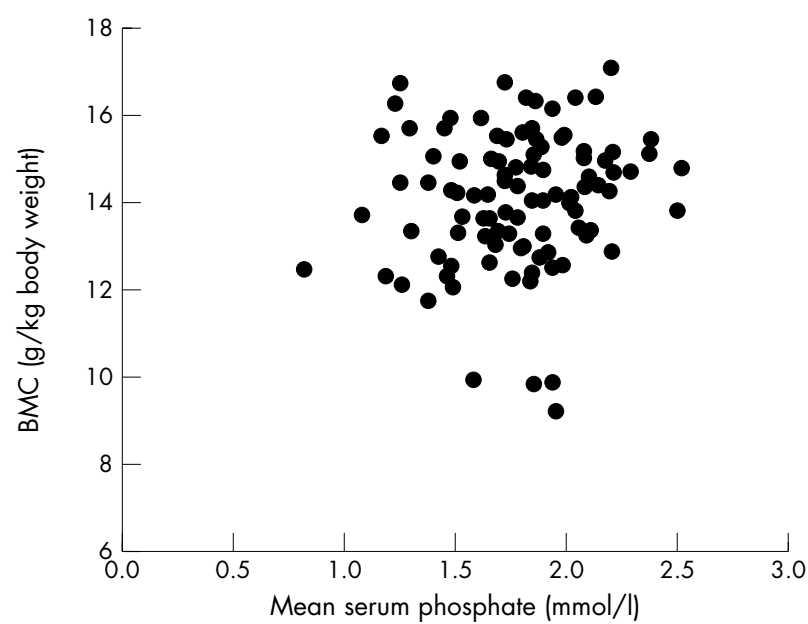

Figure 4 Association between bone mineral content (BMC) and serum phosphate. BMC at term was not associated with mean serum phosphate measured at weekly intervals during hospital stay $(p=0.21)$

infants with major movement artefacts did not differ significantly from the 108 analysed infants (869 (382) v 954 (361) $\mathrm{U} / \mathrm{l}, \mathrm{p}=0.47$, and 1.71 (0.42) $v 1.78(0.32) \mathrm{mmol} / \mathrm{l}, \mathrm{p}=0.51$ respectively).

Serum alkaline phosphatase and phosphate were measured weekly from 1 week of age until 37 weeks of gestational age, at which point most infants were discharged. Alkaline phosphatase was measured colorimetrically in $11 \mu \mathrm{l}$ serum by following hydrolysis of p-nitrophenyl phosphate to yellow coloured p-nitrophenol. Phosphate was measured in $10 \mu \mathrm{l}$ serum as inorganic phosphate, which, together with ammonium molybdate and aminophenol sulphate, forms a stable blue complex which can be measured colorimetrically. The local infant reference range for serum alkaline phosphatase is 150-600 U/l and for serum phosphate 1.45-2.17 mmol/l. Capillary blood was sampled routinely in the morning before a feed.

BMC was measured by DEXA with a whole body scanner (Hologic QDR 1000/W) operated in the single beam mode and using the Infant Whole Body Software 5.61P. The method has previously been described in detail. ${ }^{18}$. The naked infant was wrapped in a cotton napkin and placed in the prone position on a paediatric scan platform. Measurements were performed 
Table 2 Serum alkaline phosphatase and bone mineral content (BMC) and $\mathrm{BMC} / \mathrm{kg}$ body weight

\begin{tabular}{lll}
\hline $\begin{array}{l}\text { Mean alkaline } \\
\text { phosphatase }\end{array}$ & $\mathrm{BMC}(\mathrm{g})$ & $\mathrm{BMC} / \mathrm{kg}(\mathrm{g} / \mathrm{kg})$ \\
\hline$<600 \mathrm{U} / \mathrm{I}(\mathrm{n}=14)$ & $46.1(13.3)$ & $14.4(1.8)$ \\
$>1200 \mathrm{U} / \mathrm{l}(\mathrm{n}=23)$ & $43.3(9.5)$ & $13.9(1.6)$ \\
$\mathrm{p}$ Value & 0.37 & 0.46 \\
\hline
\end{tabular}

Values are mean (SD).

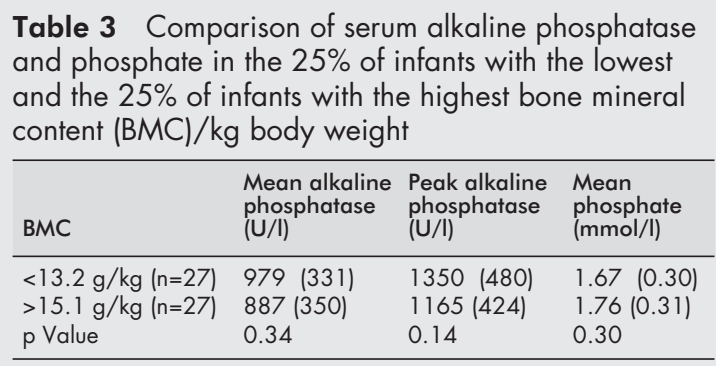

Values are mean (SD)

after a feed, when the infant was quiet and in most cases asleep to avoid movement artefacts. No sedatives were used. Mean (SD) age at DEXA scan was 41.0 (1.1) weeks of gestational age.

The target dietary intake was $200 \mathrm{ml} / \mathrm{kg} /$ day from 1 week until 37 weeks of gestational age; the actual mean intake was $191 \mathrm{ml} / \mathrm{kg} /$ day (range 167-227). Dietary intake during the intervention period has previously been described in detail. ${ }^{18}$ In this study the details were as follows: own mothers milk only $(\mathrm{n}=17)$; human milk (own mothers milk and/or donated human milk) with $100 \mathrm{mg} / \mathrm{l}$ phosphate $(\mathrm{n}=32)$; human milk with fortifier (Eoprotin) with $170 \mathrm{mg} / \mathrm{l}$ phosphate, $250 \mathrm{mg} / \mathrm{l}$ calcium, and $4 \mathrm{~g} / \mathrm{l}$ protein $(\mathrm{n}=35)$; or preterm formula (Preaptamil) with $350 \mathrm{mg} / \mathrm{l}$ phosphate, $700 \mathrm{mg} / \mathrm{l} \mathrm{cal-}$ cium, and $2.0 \mathrm{~g} / \mathrm{l}$ protein $(\mathrm{n}=24)$. The intervention period was from 1 week of age until 36 weeks of gestational age, or discharge, whichever came first. Mean (SD) duration of the intervention was 40 (14) days. After the intervention the infants were either breast fed or fed a term infant formula. There was limited use of parenteral nutrition (intravenous fluids) in $87 \%$ of the infants comprising less than $12 \%$ of the total intake during the intervention period. All infants received 800 IU vitamin D daily from 1 week of age. The study was approved by the scientific ethics committee of Copenhagen and Frederiksberg.

\section{Statistical analysis}

Major biochemical variables were mean serum alkaline phosphate and mean serum phosphate (both calculated from area under the curve), peak serum alkaline phosphatase, and time to reach peak serum alkaline phosphatase (days). The major outcome variable, BMC, was expressed as $\mathrm{g} / \mathrm{kg}$ body weight, as total body BMC is closely associated with body weight. To avoid size related artefacts, ${ }^{8}$ we have previously shown that correcting for body weight is necessary in the assessment of mineralisation. ${ }^{18}$

Linear regression analysis was performed on continuous data for BMC and the biochemical outcome variables. Unpaired $t$ test was used to analyse grouped data according to $\mathrm{BMC}$ at term and mean serum alkaline phosphatase.

\section{RESULTS}

Serum alkaline phosphatase was significantly negatively associated with serum phosphate (alkaline phosphatase $=1753-443 \times$ phosphate; $95 \%$ confidence interval
(CI) -653 to $-233 ; \mathrm{p}<0.001$ ) (fig 1). Mean serum alkaline phosphatase was not associated with BMC at term $(\mathrm{BMC}=14.2-0.00016 \times$ alkaline phosphatase; $95 \% \mathrm{CI}$ -0.0010 to $0.0007 ; p=0.71$ ) (fig 2 ). Neither peak serum alkaline phosphatase $(\mathrm{BMC}=14.4-0.0003 \times$ peak alkaline phosphatase; $95 \% \mathrm{CI}-0.0009$ to $0.0003 ; \mathrm{p}=0.5$ ) (fig 3) nor mean serum phosphate $(\mathrm{BMC}=13.0+0.60 \times$ phosphate; $95 \% \mathrm{CI}$ -0.35 to $1.55 ; \mathrm{p}=0.2$ ) (fig 4 ) was associated with BMC at term. The time to reach peak serum alkaline phosphatase was not associated with BMC $(\mathrm{BMC}=14.2-0.004 \times$ time to peak alkaline phosphatase; $95 \% \mathrm{CI}-0.020$ to $0.013 ; \mathrm{p}=0.53$ ).

BMC in a subgroup of infants with normal serum alkaline phosphatase $(<600 \mathrm{U} / \mathrm{l})$ was compared with infants with high serum alkaline phosphatase ( $>1200 \mathrm{U} / \mathrm{l})$; no significant difference $(\mathrm{p}=0.46)$ was found (table 2$)$. In a further analysis, we compared the $25 \%$ of the infants $(n=27)$ with the lowest BMC with the $25 \%$ of the infants with the highest BMC (table 3); we did not find any significant difference in mean serum alkaline phosphatase $(\mathrm{p}=0.34)$, peak serum alkaline phosphatase $(p=0.14)$, or mean serum phosphate $(\mathrm{p}=0.30)$.

\section{DISCUSSION}

We found no association between either serum alkaline phosphatase or serum phosphate and bone mineralisation at term. This is in contrast with other studies that measured BMC, although only in the forearm by photon absorptiometry. ${ }^{72}$ The study by Ryan et $a l^{13}$ compared BMC and serum alkaline phosphatase and phosphate measured on the same day on 134 occasions in 71 infants. They found an association between serum alkaline phosphatase and phosphate and BMC, but the prediction of BMC was poor because the biochemical variables could only explain $7 \%$ of the variation in BMC, and repeated measures were not accounted for. Abrams et al found a significant positive association at 16 and 25 weeks of age between serum alkaline phosphatase and BMC measured by single photon absorptiometry (SPA), also when bone width was corrected for. When assessing the predictive role of serum alkaline phosphatase or phosphate in relation to BMC, it is important to have a precise measure of BMC. As serum alkaline phosphatase and phosphate could also be associated with growth, it is important to differentiate between associations with growth parameters and BMC. Correcting for bone width in SPA measurements of BMC has been used to calculate bone mineral density, but density cannot be assessed from one size parameter, as it should be calculated as $\mathrm{g} / \mathrm{cm}^{3}$. The use of bone mineral density expressed as $\mathrm{g} / \mathrm{cm}$ or $\mathrm{g} / \mathrm{cm}^{2}$ has been shown to lead to false conclusions because of the incorrect size correction. $^{8}$

Lucas et a ${ }^{19}$ divided 852 infants with birth weight $<1850 \mathrm{~g}$ into groups according to peak serum alkaline phosphatase. A peak value $>1200 \mathrm{IU} / \mathrm{l}$ was found to be associated with reduced linear growth in the neonatal period and reduced height achievement at 18 months of age. They suggested that this may be due to metabolic bone disease, but did not actually measure BMC. When we compared infants with high serum alkaline phosphatase (mean value $>1200 \mathrm{U} / \mathrm{l}$ ) with those with low values (mean value $<600 \mathrm{U} / \mathrm{l}$ ), we found no difference in BMC at term. We have previously reported a significant association between growth velocity and serum phosphate. ${ }^{20}$ As serum phosphate is closely negatively associated with serum alkaline phosphatase, it is likely that serum alkaline phosphatase is negatively associated with growth velocity, although this may not be due to a mineralisation deficit, but rather to phosphorus deficiency.

Biochemical variables have been followed during mineral supplementation in relation to both the amount of supplementation and BMC. Gross ${ }^{21}$ found, in an unblinded study of 46 infants, a significantly higher level of serum phosphate and lower levels of serum alkaline phosphatase in infants fed 
human milk supplemented with formula compared with infants fed human milk alone or with a fortifier, but no difference was found in BMC. MacMahon et al ${ }^{22}$ reported a significant association between high serum alkaline phosphatase and BMC assessed from radiographs or low serum phosphate and rickets, but again with $x$ ray examination the BMC cannot be measured and hence size correction is not possible.

No studies on premature infants have so far reported on the association between serum alkaline phosphatase or phosphate and whole body BMC. The more precise and accurate method of DEXA used in this study may partly explain why our results differ from many others. Only three studies ${ }^{13}{ }^{16}{ }^{17}$ have directly investigated whether there is an association between serum alkaline phosphatase and/or phosphate and bone mineralisation, and they all measured regional BMC. The other studies $^{17^{14}}$ that compared BMC with serum alkaline phosphatase and/or phosphate were designed for other purposes and mainly examined associations between different diets and serum alkaline phosphatase or phosphate.

Bone mineralisation is the result of osteoblasts forming matrix vesicles. Alkaline phosphatase in the vesicle membrane transports phosphate into the vesicle. Calcium diffuses passively through the membrane, and, together with phosphate, forms the crystallisation product. When enough mineral has been crystallised, the vesicle ruptures and alkaline phosphatase is released. Therefore serum alkaline phosphatase could be regarded as an indicator of the active crystallisation process. Active and usually more efficient crystallisation also takes place in utero, but serum alkaline phosphatase is always low in the first few days of life, when bone mineralisation is thought to occur at an almost normal rate, as reflected by the fall in serum calcium. As shown in our study, serum alkaline phosphatase is significantly negatively associated with serum phosphate. Regarding high serum alkaline phosphatase as a sign of phosphorus deficiency in the bone mineralisation process would explain the lack of association between BMC and serum alkaline phosphatase. A rise in serum alkaline phosphatase makes it possible to transport more phosphate into the vesicles but only if phosphate is available. This situation could arise when there is a surplus of calcium available for crystallisation. Low or normal levels of serum alkaline phosphatase may indicate that crystallisation continues at a normal rate or at a rate where the calcium level in the vesicles is equivalent to the phosphate level.

BMC is highly significantly associated with body weight and to a much lesser extent with dietary mineral or vitamin D intake. ${ }^{518}$ Prevention of metabolic bone disease should focus on promotion of adequate growth. The growth of the very premature infant is almost completely due to an increase in lean body mass until about one month before term. Adequate increases in lean body mass require high intakes of protein and phosphorus. The intake of protein and phosphorus can be estimated by measuring the content in the milk offered to the infant or by regular measurements of serum urea and serum phosphate. ${ }^{2023}$

The conclusion from this study of 108 premature infants with a wide range of levels of serum alkaline phosphatase, serum phosphate, and whole body BMC is that there is no association between serum alkaline phosphatase or phosphate and whole body BMC at term. The routine measurement of serum alkaline phosphatase and phosphate is therefore of no use in predicting bone mineralisation in premature infants but could still be of value in relation to growth.

\section{Authors' affiliations}

J Faerk, B Peitersen, Department of Paediatrics, University Clinic of Paediatrics, Hvidovre Hospital, 2650 Hvidovre, Copenhagen, Denmark S Petersen, Department of Neonatology, Rigshospitalet, Blegdamsvej 9, 2100 Copenhagen

K F Michaelsen, Research Department of Human Nutrition, The Royal Veterinary and Agricultural University, 1958 Frederiksberg C, Denmark

\section{REFERENCES}

1 James JR, Congdon PJ, Truscott J, et al. Osteopenia of prematurity. Arch Dis Child 1986;61:871-6.

2 Horsman A, Ryan SW, Congdon PJ, et al. Osteopenia in extremely low birth weight infants. Arch Dis Child 1989;64:485-8.

3 Venkataraman PS, Blick KE. Effect of mineral supplementation of human milk on bone mineral content and trace element metabolism. J Pediatr $1988 ; 113: 220-4$.

4 Ryan S. Nutritional aspects of metabolic bone disease in the newborn. Arch Dis Child Fetal Neonatal Ed 1996;74:F145-8.

5 Rigo J, De Curtis M, Pieltain C, et al. Bone mineral metabolism in the micropremie. Clin Perinatol 2000;27:147-70.

6 Kovar I, Mayne P, Barltrop D. Plasma alkaline phosphatase activity: a screening test for rickets in preterm neonates. Lancet 1982;i:308-10.

7 Abrams SA, Schanler RJ, Garza C. Relation of bone mineralisation measures to serum biochemical measures. American Journal of Diseases in Children 1988;142:1276-8.

8 Prentice A, Parsons TJ, Cole TJ. Uncritical use of bone mineral density in absorptiometry may lead to size-related artifacts in the identification of bone mineral determinants. Am J Clin Nutr 1994;60:837-42.

9 Koo WWK, Gupta JM, Nayanar VV, et al. Skeletal changes in preterm infants. Arch Dis Child 1982;57:447-52.

10 Brunton JA, Weiler HA, Atkinson SA. Improvement in the accuracy of dual energy X-ray absorptiometry for whole body and regional analysis of body composition: validation using piglets and methodologic considerations in infants. Pediatr Res 1997:41:590-6.

11 Lapillonne A, Braillon PM, Delmas PD, et al. Dual-energy X-ray absorptiometry in early life. Horm Res 1997;48:43-9.

12 Koo WWK, Sherman R, Succop P, et al. Serum vitamin D metabolites in very low birth weight infants with and without rickets and fractures. J Pediatr 1989:114:1017-22.

13 Ryan SW, Truscott J, Simpson M, et al. Phosphate, alkaline phosphatase and bone mineralisation in preterm neonates. Acta Paediat 1993;82:518-21.

14 Bishop NJ, King FJ, Lucas A. Increased bone mineral content of preterm infants fed with a nutrient enriched formula after discharge from hospital. Arch Dis Child 1993;68:573-8.

15 Tsukahara H, Sudo M, Umezaki M, et al. Measurement of lumbar spine bone mineral density in preterm infants by dual-energy X-ray absorptiometry. Biol Neonate 1993;64:96-103.

16 Crofton PM, Shrivastava A, Wade JC, et al. Bone and collagen markers in pretrem infants: relationship with growth and bone mineral content over the first 10 weeks of life. Pediatr Res 1999;46:581-7.

17 Backström MC, Kouri T, Sievänen $H$, et al. Bone isoenzyme of serum alkaline phosphatase and serum inorganic phosphate in metabolic bone disease of prematurity. Acta Paediatr 2000;89:867-73.

18 Faerk J, Petersen S, Peitersen B, et al. Diet and bone mineral content at term in premature infants. Pediatr Res 2000;47:148-56.

19 Lucas A, Brooke OG, Baker BA, et al. High alkaline phosphatase and growth in preterm neonates. Arch Dis Child 1989:64:902-9.

20 Faerk J, Petersen S, Peitersen B, et al. Phosphorus intake is of major importance for growth velocity in premature infants. Pediatr Res 1999;45:915.

21 Gross SJ. Bone mineralization in preterm infants fed human milk with and without mineral supplementation. J Pediatr 1987;111:450-8.

22 MacMahon $\mathbf{P}$, Blair ME, Treweeke $P$, et al. Association of mineral composition of neonatal intravenous feeding solutions and metabolic bone disease of prematurity. Arch Dis Child 1989;64:489-93.

23 Polberger SK, Axelsson IE, Räihä NC. Urinary and serum urea as indicators of protein metabolism in very low birth weight infants fed varying human milk protein intakes. Acta Paediatr Scand 1990;79:737-42. 